\title{
Faktor-Faktor yang Memengaruhi Status Nutrisi Akut Pascabedah
}

\author{
Yusrina Istanti, ${ }^{* * *}$ Antonius Pudjiadi, * Abdul Latief, ${ }^{*}$ Sri Martuti, ${ }^{* *}$ Moh. Supriatna, ${ }^{* * *}$ \\ Pudjiastuti** \\ "Departemen Ilmu Kesehatan Anak Fakultas Kedokteran Universitas Indonesia/RS Cipto Mangunkusumo, \\ Jakarta, "Bagian Ilmu Kesehatan Anak Fakultas Kedokteran Universitas Sebelas Maret/RSUD Dr. \\ Moewardi, Surakarta, ${ }^{* * *}$ Departemen Ilmu Kesehatan Anak Fakultas Kedokteran Universitas Diponegoro/ \\ RSUP Dr. Kariadi, Semarang
}

\begin{abstract}
Latar belakang. Malnutrisi sering ditemukan pada pasien pascabedah dan berhubungan dengan penurunan fungsi otot, respirasi, imun serta penyembuhan luka yang terganggu. Tindakan pembedahan merupakan stresor yang memicu respons metabolik sehingga berpengaruh terhadap luaran, termasuk status nutrisi. Tujuan. Mengetahui faktor-faktor yang memengaruhi status nutrisi akut pascabedah.

Metode. Penelitian observasional analitik dilakukan di ICU anak tiga rumah sakit, yaitu RS Cipto Mangunkusumo, RS Dr Kariadi, dan RSUD Dr Muwardi. Dilakukan pemeriksaan kadar retinol binding protein (RBP) hari ke-1 dan ke-5 pascabedah sebagai indikator status nutrisi, kortisol, dan $C$-reactive protein (CRP) sebagai marker respons inflamasi. Status nutrisi berdasarkan antropometri dinilai, jenis, dan lama pembedahan dicatat. Dilakukan uji korelasi untuk melihat hubungan antara kortisol, CRP, dan RBP dengan kadar RBP hari ke-5. Uji kai kuadrat untuk melihat hubungan status nutrisi, jenis dan lama pembedahan dengan kadar RBP hari ke-5.

Hasil. Selama kurun waktu 6 bulan didapatkan 39 subjek yang memenuhi kriteria inklusi dan 4 subjek dieksklusi. Penurunan kadar RBP hari ke-5 dijumpai pada 12 (34,4\%) subjek. Didapatkan hubungan antara kadar kortisol, CRP, dan RBP hari ke-1 dengan kadar RBP hari ke-5 [r=-0,35 (p=0,04); r=-0,53 ( $\mathrm{p}=0,001)$; $\mathrm{r}=0,42(\mathrm{p}=0,01)]$. Tidak terdapat hubungan antara status nutrisi berdasarkan antropometri serta jenis dan lama pembedahan dengan kadar RBP hari ke-5 ( $>00,05)$.

Kesimpulan. Terdapat hubungan antara kadar RBP hari ke-1 dan ke- 5 sebagai parameter status nutrisi akut pascabedah. Kadar RBP hari ke-5 tidak dipengaruhi oleh status nutrisi prabedah serta jenis dan lama pembedahan, tetapi oleh kadar kortisol dan CRP sebagai marker respons stres. Sari Pediatri 2014;16(3):215-20
\end{abstract}

Kata kunci: malnutrisi akut, pascabedah, RBP, CRP

\footnotetext{
Alamat korespondensi:

Dr. Yusrina Istanti, SpA. Bagian IKA FK-UNDIP/RSUP Dr. Kariadi. J1. Dr. Sutomo 14, Semarang, Jawa Tengah. Telp. +6224-8414296. Email: yit1st@idai.or.id,yit1st@gmail.com
}

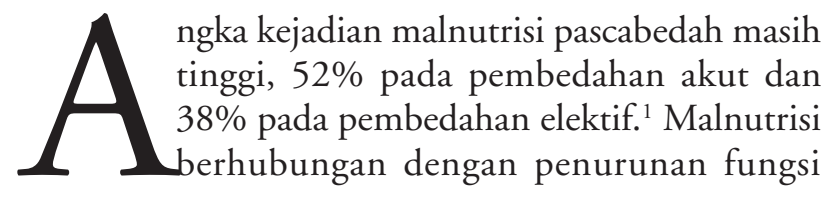


otot, respirasi, imun, dan proses penyembuhan luka. Penyebab malnutrisi pascabedah adalah multifaktorial dan secara garis besar dapat dikelompokkan menjadi dua, yaitu 1) meningkatnya kebutuhan energi sekunder akibat respons stres, 2) kesulitan dalam menentukan kebutuhan energi dan pemilihan substrat. ${ }^{2}$

Pada keadaan stres, termasuk pada pembedahan, kebutuhan energi dapat berbanding lurus dengan lama dan derajat paparan, tetapi tidak dapat ditentukan secara tepat. Kegagalan pemberian kalori dan protein secara adekuat pada tahap ini, baik kurang (underfeeding) maupun lebih (overfeeding), akan memperburuk status nutrisi dan memengaruhi luaran. Imbalans energi yang besar harus dihindari dengan cara menilai kebutuhan nutrisi secara individual pada setiap pasien dan selalu mengevaluasi secara teratur. Untuk dapat memberikan nutrisi secara tepat diperlukan pemahaman yang benar tentang apa yang terjadi pada stres metabolik. Gambaran profil hormon dan sitokin yang khas pada keadaan stres metabolik dapat berupa 1) meningkatnya kadar hormon insulin, glukagon, kortisol, katekolamin, dan sitokin proinflamasi, 2) terjadinya resistensi insulin dan GH yang dipicu peningkatan hormon counterregulatory, 3) terjadinya katabolisme protein, karbohidrat, dan lemak endogen.,3

Di tingkat sel hepatosit, respons fase akut mengakibatkan perubahan produksi protein fase akut. Peningkatan kortisol maupun sitokin proinflamasi akan merangsang peningkatan produksi protein fase akut positif dan menurunkan produksi protein fase akut negatif. Protein fase akut positif memiliki fungsi, antara lain untuk opsonisasi dan menghilangkan mikro-organisme dan produknya, aktivasi komplemen, modulasi respons imun host. C-reaktif protein adalah salah satu protein fase akut positif utama pada pembedahan yang dapat menunjukkan derajat inflamasi. ${ }^{4-6}$

Identifikasi malnutrisi berdasarkan penurunan berat badan atau indeks massa tubuh (IMT) pada pasien pascabedah seringkali tidak relevan. Pada kasus ini sering dilakukan resusitasi cairan dalam jumlah besar sehingga perubahan berat badan belum tentu menggambarkan perubahan status nutrisi. Protein viseral albumin, pre-albumin, dan retinol binding protein (RBP) sering digunakan sebagai indikator nutrisi pada keadaan ini. Albumin secara rutin diperiksa pada pasien pascabedah. Keterbatasan albumin adalah memiliki waktu paruh panjang dan dipengaruhi oleh banyak faktor, seperti dehidrasi, status inflamasi, kehilangan protein maupun pemberian albumin. Prealbumin dan RBP memiliki waktu paruh pendek dan terbukti cukup sensitif untuk indikator nutrisi akut. ${ }^{7}$ Banyak uji klinis yang membuktikan bahwa RBP dan PA mempunyai korelasi langsung dengan kehilangan energi-protein dan terapi nutrisi. Ingenbleek $\mathrm{dkk}^{8}$ dalam penelitiannya pada anak dengan malnutrisi, menemukan bahwa pada keadaan malnutrisi akut kadar RBP turun hingga 31\% dari kadar normal. Peningkatan kadar RBP terjadi secara cepat dengan pemberian nutrisi yang adekuat. Pada minggu pertama, peningkatan kadar RBP 2x lipat dibandingkan sebelumnya, dan minggu kedua 3 kali lipat. Kadar RBP yang rendah dalam kondisi malnutrisi diduga karena berkurangnya proses sintesis di hati.

Dalam penelitiannya pada pasien dewasa obes, Shetty $\mathrm{dkk}^{9}$ menemukan bahwa PA dan RBP lebih sensitif untuk menilai terapi diet dibanding albumin dan dan transferin. Pada penelitian ini ditemukan juga bahwa RBP lebih sensitif dibanding PA untuk menilai asupan diet baik energi maupun protein. Peneliti merekomendasikan pemeriksaan kadar PA atau RBP untuk mengetahui terjadinya malnutrisi yang secara klinis belum terlihat (malnutrisi subklinis), atau untuk menilai respons terhadap terapi diet baik enteral maupun parenteral.

Penelitian bertujuan mendapatkan angka kejadian malnutrisi akut pascabedah berdasarkan perubahan kadar RBP dan menganalisis faktor-faktor yang memengaruhinya, termasuk parameter respons stres seperti kortisol dan protein fase akut. Hasil penelitian diharapkan dapat digunakan sebagai acuan dalam tatalaksana pasien pascabedah selanjutnya.

\section{Metode}

Studi observasional analitik yang dilaksanakan di ruang rawat intensif anak (Pediatric Intensive Care Unit/PICU) dan bangsal rawat bedah RS Dr. Cipto Mangunkusumo (RSCM) Jakarta, RSUP Dr. Kariadi Semarang, dan RSUD Dr. Moewardi Surakarta. Subjek adalah pasien berusia 1 bulan - 18 tahun yang mengalami pembedahan mayor. Subjek dieksklusi dari penelitian apabila mengalami disfungsi hati berat yang ditandai dengan peningkatan kadar ALT $>2 \mathrm{x}$ normal berdasarkan umur. Alur penelitian tertera pada Gambar 1. 
Yusrina Istanti dkk: Faktor-faktor yang memengaruhi status nutrisi akut pascabedah

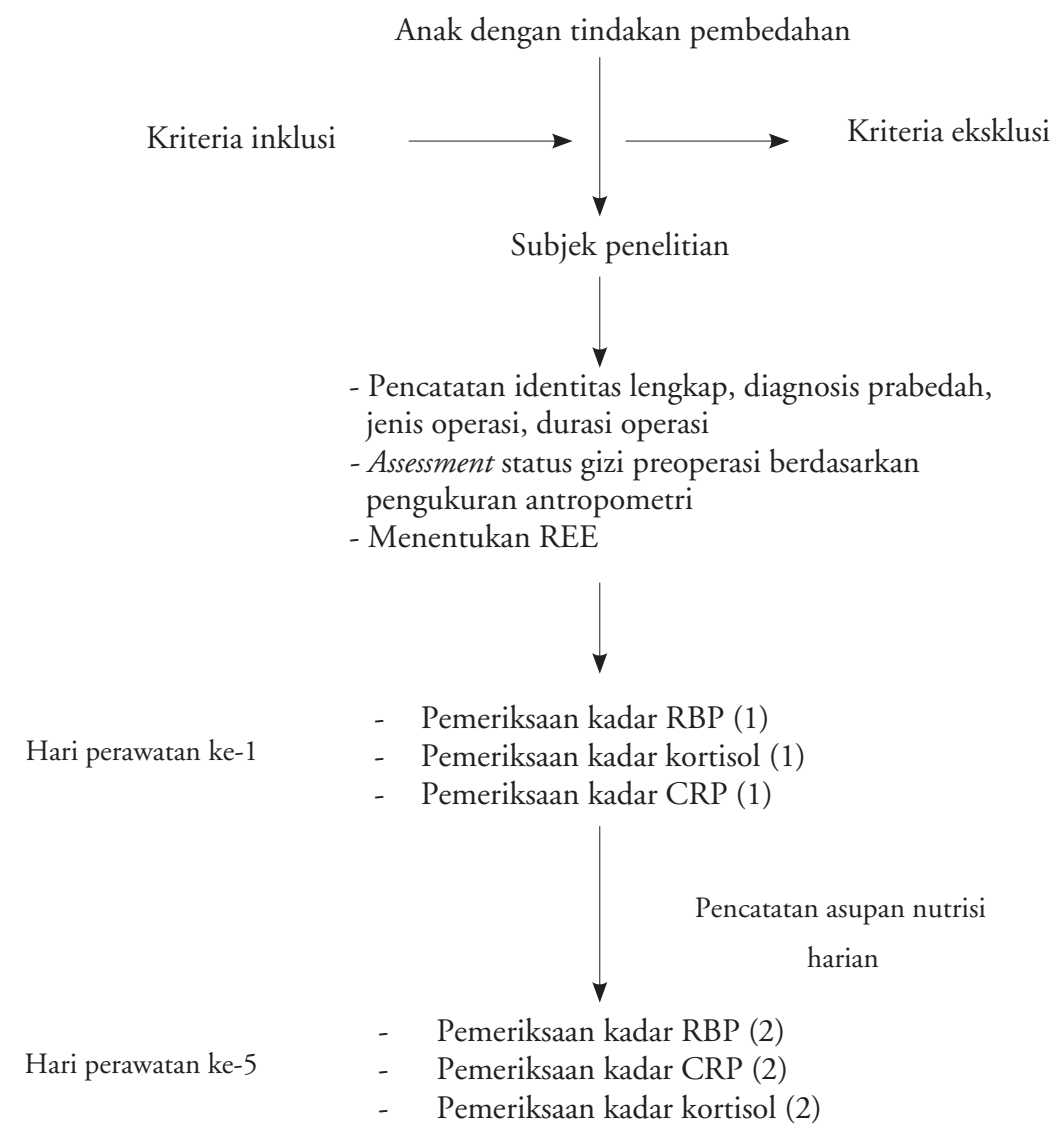

Gambar 1. Alur penelitian

\section{Hasil}

Jumlah keseluruhan 39 subjek penelitian yang terkumpul dan memenuhi kriteria inklusi. Empat subjek tidak melanjutkan penelitian, 2 dipulangkan sebelum pengambilan darah hari ke-5, dan 2 meninggal. Karakteristik subjek yang didapatkan dari anamnesis dan hasil pemeriksaan laboratorium tertera pada Tabel 1. Sebagian besar subjek penelitian adalah laki-laki 21(60\%). Pasien dengan status gizi prabedah adalah gizi baik $21(60 \%)$ pasien. Jenis pembedahan terbanyak adalah bedah syaraf $18(51,4 \%)$ dan yang paling sedikit adalah bedah ortopedi $3(8,6 \%)$. Lama operasi tersingkat adalah 60 menit dan terlama adalah 600 menit. Berdasarkan kategori lama operasi terbanyak adalah $\leq 2$ jam.

Terdapat $12(33,4 \%)$ pasien mengalami penurunan kadar RBP hari ke-5 dibandingkan hari ke-1. Empat pasien berasal dari kelompok gizi kurang dan 8 pasien
Tabel 1. Karakteristik subjek penelitian

\begin{tabular}{lc}
\hline Karakteristik & Nilai \\
\hline Jenis kelamin (\%) & \\
$\quad$ Laki-laki & $21(60)$ \\
$\quad$ Perempuan & $14(40)$ \\
Umur, bulan, rerata (SB) & $68,7(61,4)$ \\
Tinggi badan, cm, rerata (SB) & $102,2(37,6)$ \\
Berat badan, kg, rerata (SB) & $18,4 \pm 13,31(2,4-52)$ \\
Status gizi prabedah (\%) & \\
$\quad$ Baik & $21(60)$ \\
$\quad$ Kurang & $14(40)$ \\
Jenis pembedahan (\%) & \\
$\quad$ Syaraf & $18(51,4)$ \\
$\quad$ Abdomen & $14(40)$ \\
$\quad$ Ortopedi & $3(8,6)$ \\
Lama operasi,menit, rerata(SB) & $138,1 \pm 100,40$ \\
Kategori lama operasi (jam, \%) & \\
$\quad \leq 2$ & $22(62,9)$ \\
$\quad>2$ & $13(37,1)$ \\
\hline
\end{tabular}


Tabel 3. Hubungan kadar kortisol dan CRP dengan kadar RBP hari ke-5

\begin{tabular}{ccc}
\hline Variabel & $\mathrm{r}$ & $\mathrm{p}$ \\
\hline Kortisol & & \\
I & $+0,03$ & 0,9 \\
II & $-0,35$ & 0,04 \\
CRP & & \\
I & $-0,02$ & 0,9 \\
II & $-0,53$ & 0,001 \\
\hline
\end{tabular}

Keterangan: analisis dengan uji korelasi Spearman

CRP (C-Reactive protein), RBP (Retinol binding protein), I (pemeriksaan pada hari ke-1),

II (pemeriksaan pada hari ke-5)

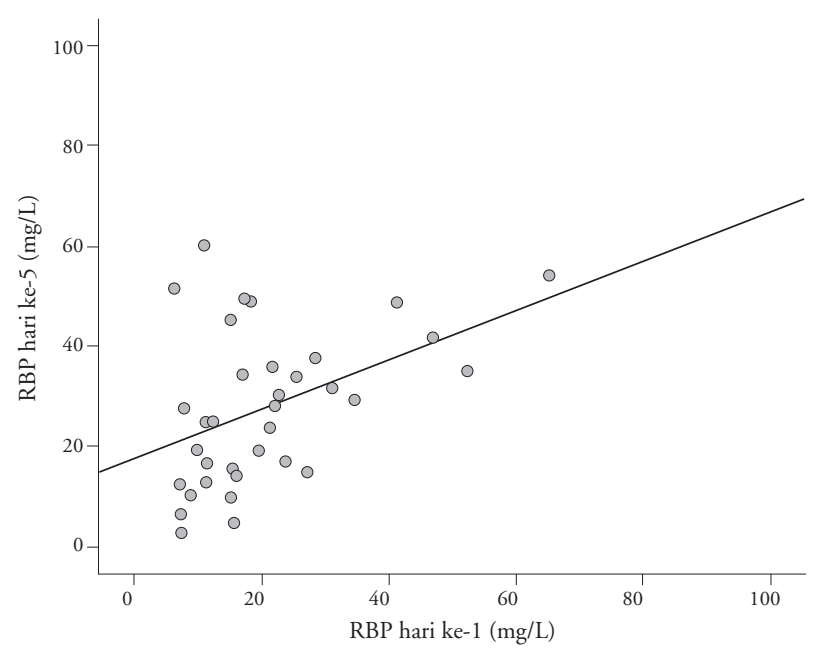

Gambar 2. Hubungan antara status nutrisi berdasar RBP hari ke-1 dengan kadar RBP hari ke-5

Tabel 4. Hubungan antara berbagai pengelompokan variabel dengan penurunan kadar RBP

\begin{tabular}{lcc}
\hline Variabel & $\mathrm{n}(\%)$ & $\mathrm{p}$ \\
\hline Jenis pembedahan & & 0,6 \\
Bedah syaraf & $7(38,9)$ & \\
I & $11(61,1)$ & \\
II & $5(35,7)$ & \\
Bedah abdomen & $9(64,3)$ & \\
I & $0(0)$ & \\
II & $3(100)$ & \\
Bedah ortopedi & & \\
I & $7(31,8)$ & \\
II & $15(68,2)$ & \\
Lama pembedahan & & \\
$\leq 2$ jam & $5(38,5)$ & \\
I & $8(61,5)$ & \\
II & & \\
$>2$ jam & & \\
I & & \\
II & $8(38,1)$ & \\
Status nutrisi prabedah berdasarkan antropometri & \\
Gizi baik & $13(61,9)$ & \\
I & & \\
II & $4(28,6)$ & \\
Gizi kurang & $10(71,4)$ & \\
I & & \\
II & & \\
\end{tabular}

Keterangan: analisis dengan uji Kai kuadrat

I (Kelompok dengan kadar RBP hari ke-5 turun), II (Kelompok dengan kadar RBP hari ke-5 normal) 
dari kelompok gizi baik berdasarkan antropometri.

Terdapat hubungan antara status nutrisi berdasarkan kadar RBP hari ke-1 dengan hari ke-5 ( $r=0,42$, $\mathrm{p}=0,01)$. Kadar RBP hari ke-1 yang tinggi akan diikuti peningkatan hari ke-5. Kadar RBP hari ke-1 yang rendah akan diikuti penurunan hari ke-5.

Rerata kadar kortisol hari ke-5 terjadi penurunan dibandingkan hari ke-1, tetapi secara statistik tidak bermakna $(\mathrm{p}=0,9)$. Rerata kadar CRP hari ke-5 juga mengalami peningkatan, meskipun secara statistik tidak bermakna $(\mathrm{p}=0,4)$.

Terdapat hubungan antara kadar kortisol hari ke- 5 dengan kadar RBP hari ke-5 ( $r=-0,35, p=0,04)$ dan kadar CRP hari ke-5 dengan kadar RBP hari ke-5 ( $\mathrm{r}=$ $-0,53, p=0,001)$.

Pada kelompok dengan status nutrisi prabedah, dijumpai $8(38,1 \%)$ pasien gizi baik dengan kadar RBP hari ke-5 yang turun dan $4(28,6 \%)$ gizi kurang. Pada berbagai jenis pembedahan, $7(38,9 \%)$ pasien dengan RBP hari ke-5 yang turun didapatkan pada kelompok pasien bedah syaraf, abdomen, dan ortopedi. Berdasarkan lama pembedahan, kadar RBP hari ke-5 yang turun didapatkan $7(31,8 \%)$ pasien pada kelompok dengan lama pembedahan $\leq 2$ jam dan $5(38,5 \%)$ pasien $>2$ jam. Uji Kai kuadrat dilakukan untuk melihat hubungan antara jenis pembedahan, lama pembedahan, dan status nutrisi prabedah dengan kadar RBP hari ke- 5 dengan hasil tidak bermakna ( $>00,05)$.

\section{Pembahasan}

Pada pembedahan mayor, terjadi respons fase akut yang ditandai dengan perubahan pada neuro-endokrin, metabolik, dan respons inflamasi. Impuls aferen dari tempat pembedahan mengaktifkan sistem saraf simpatis dan hypotalamus-pituitary axis (HPA). Terjadi pelepasan releasing factor dari hipotalamus (corticotropin releasing factor/CRF), somatrotropin dan vasoactive intestinal peptide) selanjutnya menyebabkan hipofise teraktivasi melepaskan hormon ACTH dan GH. Secara umum, pada kondisi ini akan dilepaskan hormon katabolik seperti kortisol dan hormon hipofise, sementara hormon anabolik insulin akan ditekan. Hal tersebut bertujuan untuk kelangsungan hidup dengan cara memobilisasi substrat, membatasi kerusakan jaringan, membunuh organisme yang menimbulkan infeksi, dan mengaktivasi proses penyembuhan. Di tingkat sel hepatosit, respon fase akut mengakibatkan reprioritisasi produksi protein fase akut. Peningkatan kortisol maupun sitokin pro-inflamasi akan merangsang peningkatan produksi protein fase akut positif dan menurunkan produksi protein fase akut negatif. Protein fase akut positif, terutama CRP, memiliki fungsi antara lain untuk opsonisasi dan menghilangkan mikro-organisme dan produknya, aktivasi komplemen, modulasi respon imun host. Kadar CRP dan kortisol plasma dapat digunakan untuk menilai keadaan stres metabolik. Kadar kortisol akan meningkat segera setelah pembedahan dan kadarnya akan kembali normal pada hari ke-2, ke-4, dan ke-7. Peningkatan kadar CRP 4-6 jam pasca trauma dengan puncak setelah 24-48 jam dan pada hari ke-3 kadarnya kembali ke baseline. ${ }^{10}$ Makalah lain menyebutkan penurunan CRP terjadi secara lebih lambat. Kami mendapatkan rerata kadar kortisol menurun pada hari ke-5, sedangkan rerata kadar CRP masih lebih tinggi pada hari ke-5. Kadar CRP hari ke-5 yang masih tinggi menunjukkan respons stres yang belum reda, kemungkinan masih ada respons inflamasi akibat munculnya infeksi atau komplikasi lainnya. Letton $\mathrm{dkk}^{11}$ mengatakan bahwa kadar CRP $>2 \mathrm{mg} /$ $\mathrm{dL}$ menunjukkan masih berlangsungnya respons stres fase akut dan apabila kadarnya $\geq 6 \mathrm{mg} / \mathrm{dL}$ menunjukkan respons stres berat.

Terdapat 12 subjek yang mempunyai kadar RBP yang turun pada hari ke-5. Empat pasien berasal dari kelompok gizi kurang dan 8 pasien dari kelompok gizi baik berdasarkan antropometri. Hasil tersebut lebih besar dibandingkan penelitian Jungueira $\mathrm{dkk}^{12}$ yang mendapatkan kadar abnormal RBP 20,3\% pada pembedahan elektif. Hal tersebut disebabkan perbedaan dalam menentukan abnormalitas RBP. Pada Jungueira digunakan rerata kadar normal RBP, sedangkan pada penelitian kami digunakan trend penurunan kadar RBP.

Tidak didapatkan hubungan antara status nutrisi prabedah yang ditentukan berdasarkan pengukuran antropometri dengan kadar RBP hari ke-5. Apabila dilakukan penentuan status nutrisi berdasar biomarker, dengan membandingkan kadar RBP hari ke-5 dengan kadar RBP hari ke-1, terdapat korelasi positif yang menunjukkan bahwa apabila kadar RBP hari ke-1 tinggi maka kadar RBP hari ke-5 juga akan meningkat. Apabila kadar RBP hari ke-1 rendah maka kadar RBP hari ke-5 juga akan rendah. Hal tersebut membuktikan bahwa pada keadaan stres, marker biokimia lebih baik dalam mendiagnosis malnutrisi akut karena peningkatan dan penurunannya dapat terdiagnosis dengan cepat.

Lopez $\mathrm{dkk}^{10}$ mengatakan bahwa RBP sangat 
dipengaruhi oleh respons stres dan sedikit dipengaruhi oleh tunjangan nutrisi. Pada 12 pasien dengan RBP yang turun, faktor lain yang kemungkinan berpengaruh harus dilihat, seperti kadar kortisol dan CRP yang mewakili respons stres, munculnya komplikasi infeksi, kemungkinan ada kehilangan dari saluran cerna, seperti muntah atau diare, demam, dan lain-lain.

Keterbatasan penelitian ini adalah dilakukan pada subjek dengan jenis pembedahan yang bervariasi-bedah syaraf, abdomen, dan ortopedi-sehingga lama operasi tidak dapat mencerminkan derajat berat pembedahan termasuk kerusakan jaringan yang terjadi.

\section{Kesimpulan}

Kadar RBP hari ke-1 berkorelasi positif dengan hari ke-5 sehingga apabila kadar RBP hari pertama rendah maka hari ke- 5 akan rendah. Kadar RBP hari ke- 5 tidak dipengaruhi oleh jenis dan lama pembedahan serta status nutrisi prabedah, tetapi lebih dipengaruhi oleh respons metabolik terhadap stres (kadar kortisol dan CRP). Penelitian lanjutan dengan mengukur parameter biokimia lebih lengkap, seperti IL-6 dan IGF-1 secara serial untuk memastikan keadaan respons inflamasi yang memengaruhi status nutrisi perlu dilakukan. Penelitian dengan jenis pembedahan lebih homogen juga perlu dilakukan sehingga mendapat gambaran respons stres yang sesuai. Selain itu, status nutrisi berdasarkan antropometri dapat dibandingkan secara lebih terperinci jika penelitian dilakukan dengan subjek yang lebih banyak.

\section{Daftar pustaka}

1. Kahokehr AA, Sammour T, Wang K, Sahakian V, Plank LD, Hill AG. Prevalence of malnutrition on admission to
hospital-Acute and elective general surgical patients. The European e-journal of clinical Nutrition and Metabolism 2010;5:e21-5.

2. Mehta NM, Duggan C. Nutritional deficiencies during critical illness, Pediatr Clin Am 2009;56:1143-60.

3. Cruickshank AM, Jennings G, Fearon KH, Elia M, Shenkin A. Serum interleukin-6 (IL-6) - effect of surgery and undernutrition. Clin Nutr 1991;10:65-9.

4. Burton D, Nicholson G, Hall G. Endocrine and metabolic response to surgery. Continuing Education in Critical Care \& Pain 2004;4:144-47.

5. Blebuyk JF, Phil D. The metabolic response to stress: an overview and update. Anesthesiology 1990;73:308-27.

6. Gruys E, Toussaint MJM, Niewold TA, Koopmans SJ. Acute phase reaction and acute phase protein. J Zhejiang UnivSci 2005;11:1045-56.

7. Goldsmith B. Nutritional assessment in pediatric patients. How can the laboratory help? Pediatr Pathol Lab Med 1996;16:1-7.

8. Ingenbleek Y, Henry G, de Nayer P, de Visscher M. The role of retinol binding protein in protein calorie malnutrition. Metabolism 1975;24:633-41.

9. Shetty PS, Jung RT, Watrasiewicz KE, James WPT Rapid turnover transport protein: An index of subclinical protein-energy malnutrition, The Lancet, Agustus 1979: ii:230-2.

10. Lopez-Hellin J, Baena-Fustegueras JA, Schwartz-Riera $S$, Garcia-Arumi E. Usefulness of short-lived protein as nutritional indicators surgical patients. Clin Nutr 2002;21:119-25.

11. Letton RW, Chwals WJ, Jamie A, Charles B. Early post operative alterations in infant energy use increase the risk of overfeeding. J Pediatr Surg 1995;30:988-93.

12. Junqueria JCS, Soares EC, Filho HRC, Hoehr NF, Magro DO, Ueno M. Nutritional Risk Factors for Postoperative Complication in Brazilian Elderly Patients undergoing major Elective Surgery. Nutrition 2003;19:321-26. 